\title{
Faktor-faktor yang Mempengaruhi Kinerja Kewirausahaan Petani Kopi Arabika di Kecamatan Dolog Masagal, Kabupaten Simalungun, Provinsi Sumatera Utara
}

\author{
Factors Affecting the Entrepreneurial Performance of Arabica Coffee Farmers in Dolog \\ Masagal District, Simalungun Regency, North Sumatra Province
}

\author{
Jef Rudiantho Saragih $^{1 *}$ \& Ummu Harmain ${ }^{1}$ \\ ${ }^{1}$ Program Studi Agribisnis, Fakultas Pertanian, Universitas Simalungun, Jalan Sisingamangaraja, Kampus \\ USI Pematangsiantar 21139, Indonesia; *Penulis korespondensi. e-mail: saragihjef@ gmail.com
}

(Diterima: 30 Desember 2020; Disetujui: 22 Maret 2021)

\begin{abstract}
Arabica coffee is a leading commodity in Simalungun Regency, where entrepreneurship becomes one of the important aspects in arabica coffee farming management. This study aims to understand the influence of internal factors (farmer age, education, experience, number of family members, family motivation, and work culture) and external factors (government support, community support, access to production facilities, and climatic conditions) on entrepreneurial performance of arabica coffee farmers. The research was conducted in two villages (Bangun Pane village and Bintang Mariah village) in Dolog Masagal district, Simalungun Regency, North Sumatra Province during March to May 2018. The study sample covers 60 farmer households who have Arabica coffee farming with at least 300 arabica coffee plants and minimum plant age of three years, determined by snowball sample method. The study used ratio and scale data (Likert scale), which was analyzed using multiple regression equations. Data were processed using SPSS 24. Results show that internal factors have positive and significant effect on the entrepreneurial performance of arabica coffee farmers (value Sig.=0.005), while external factors have positive and insignificant effect (value Sig. $=0.313)$. Local governments through relevant technical agencies are recommended to provide facilitation in improving farmers' access to production factors, increasing quantity and quality of extension, technical guidance, and relevant training.
\end{abstract}

Keywords: arabica coffee, entrepreneurship, farmer, Simalungun

\begin{abstract}
ABSTRAK
Kopi arabika merupakan komoditas unggulan di Kabupaten Simalungun, dimana kewirausahaan menjadi salah satu aspek penting dalam manajemen usahatani kopi arabika. Penelitian ini bertujuan untuk mengetahui pengaruh faktor internal (umur petani, pendidikan, pengalaman, jumlah anggota keluarga, motivasi keluarga, dan budaya kerja) dan faktor eksternal (dukungan pemerintah, dukungan masyarakat, akses sarana produksi, dan kondisi iklim) terhadap kinerja kewirausahaan petani kopi arabika. Penelitian dilaksanakan di dua desa (Bangun Pane dan Bintang Mariah) di Kecamatan Dolog Masagal, Kabupaten Simalungun, Provinsi Sumatera Utara selama bulan Maret hingga Mei 2018. Sampel penelitian berjumlah 60 rumah tangga petani yang memiliki usahatani kopi arabika dengan populasi tanaman kopi arabika minimal 300 pohon dan umur tanaman kopi arabika minimal tiga tahun, ditentukan dengan metode sampel bola salju. Penelitian
\end{abstract}


menggunakan data rasio dan skala (skala Likert) yang dianalisis dengan menggunakan persamaan regresi berganda. Data diolah dengan menggunakan program SPSS 24. Hasil penelitian menunjukkan bahwa faktor internal berpengaruh positif dan nyata terhadap kinerja kewirausahaan petani kopi arabika (nilai Sig.=0.005), sementara faktor eksternal berpengaruh positif dan tidak nyata terhadap kinerja kewirausahaan petani kopi arabika (nilai Sig.=0.313). Pemerintah daerah melalui dinas teknis terkait direkomendasikan memberikan fasilitasi dalam meningkatkan akses petani terhadap sarana produksi, meningkatkan jumlah dan kualitas layanan penyuluhan, bimbingan teknis, dan pelatihan yang relevan.

Kata kunci: kewirausahaan, kopi arabika, petani, Simalungun

\section{PENDAHULUAN}

Kopi merupakan komoditas unggulan binaan secara nasional (Direktorat Jenderal Perkebunan, 2020) dan merupakan komoditas andalan yang memiliki prospektif ekspor (Direktorat Jenderal Perkebunan, 2015). Berdasarkan data International Coffee Organization (ICO) tahun 2018/2019, produksi kopi Indonesia menempati posisi keempat dalam produksi kopi dunia, setelah Brazil, Vietnam, dan Kolombia. Peran komoditas kopi yang cukup penting bagi perekonomian Indonesia dirilis oleh Direktorat Kajian Strategis dan Kebijakan Pertanian, Institut Pertanian Bogor (2017), antara lain sebagai sumber pendapatan petani, devisa, bahan baku, dan kesempatan kerja. Namun ekspor kopi masih dominan dalam bentuk biji daripada produk olahan.

Kopi arabika merupakan komoditas atau produk unggulan Sumatera Utara (Dinas Perkebunan Provinsi Sumatera Utara, 2013; Badan Penelitian dan Pengembangan Provinsi Sumatera Utara, 2019), dengan produksi tahun 2017 sebesar 58,155 ton dan menempati posisi kedua setelah Provinsi Aceh (Direktorat Jenderal Perkebunan, 2020). Di Kabupaten Simalungun, kopi arabika merupakan komoditas unggulan dengan produksi tahun 2018 sebesar 10,119 ton dan menempati posisi produksi kedua terbesar setelah Kabupaten Tapanuli Utara (Direktorat Jenderal Perkebunan, 2019). Sumarti et al. (2017) menyatakan bahwa kopi arabika merupakan produk global dan kopi arabika Simalungun mampu bersaing di dunia internasional.
Kopi arabika merupakan komoditas penting dalam kehidupan rumah tangga petani dan berperan penting dalam perekonomian lokal. Komoditas ini berperan dalam meningkatkan pendapatan petani, penyerapan tenaga kerja, dan meningkatkan aktivitas ekonomi lokal (Saragih, 2018). Di samping komoditas unggulan, sektor hilir kopi arabika menghasilkan produk olahan yang termasuk dalam salah satu produk ekonomi kreatif di segmen kuliner. Badan Penelitian dan Pengembangan Provinsi Sumatera Utara (2019) menemukan bahwa salah satu permasalahan dalam pengembangan kopi sebagai produk unggulan daerah adalah terbatasnya inovasi dalam produk olahan kopi.

Pengembangan produk olahan kopi arabika sebagai produk ekonomi kreatif memerlukan inovasi dan jiwa kewirausahaan dalam pengelolaannya. Aspek inovatif dan kewirausahaan ini bahkan perlu ditumbuhkan dan dikembangkan sejak awal di kalangan petani. Kondisi umum aspek inovatif dan kewirausahaan di kalangan petani belum seperti yang diharapkan. Berbagai hasil kajian empiris membuktikan hal tersebut. Kondisi umum tersebut berbeda dari kondisi yang ditemukan pada petani kopi arabika di Kabupaten Gayo. Zainura et al. (2016) menemukan bahwa motivasi berusahatani di kalangan petani kopi arabika berada pada kategori tinggi, persepsi terhadap keberhasilan usahatani berada pada kategori tinggi, dan keinginan mempertahankan usahatani kopi arabika pada kategori cukup tinggi.

Penelitian mengenai kinerja kewirausahaan petani kopi arabika menjadi 
penting didasarkan pada kondisi petani dan hasil penelitian empiris sebelumnya. Sumarti et al. (2017) dalam penelitian di Kabupaten Simalungun menemukan bahwa petani muda wirausaha menjadi penentu keberlanjutan usaha kopi arabika. Petani muda kopi wirausaha yang dianggap berdaya dicirikan oleh karakter wirausaha, akses dan kontrol yang kuat pada usaha kopi, dan posisi sosial yang diakui masyarakat.

Peningkatan skala usaha, motivasi berprestasi, dan persepsi terhadap usaha dapat meningkatkan perilaku kewirausahaan; sementara perilaku kewirausahaan secara signifikan berpengaruh positif terhadap kinerja usaha tani kopi arabika di Kabupaten Karo (Siahaan \& Martauli, 2019). Salah satu aspek inovatif dan praktik kewirausahaan di kalangan petani adalah adopsi budidaya Good Agricultural Practices (GAP). Hasil penelitian Mahyuda et al. (2018) menemukan bahwa tingkat kemanfaatan inovasi dan keuntungan relatif berpengaruh nyata positif terhadap tingkat adopsi budidaya GAP kopi arabika di Kabupaten Gayo. Selanjutnya, Saragih (2018) menyimpulkan bahwa praktik GAP, yaitu pemangkasan tanaman kopi dan pengendalian hama penggerek buah kopi, merupakan faktor penting untuk meningkatkan kinerja usahatani yaitu produksi kopi arabika. Zainura et al. (2016) menyimpulkan bahwa perilaku kewirausahaan berpengaruh positif dan signifikan terhadap perspektif kinerja usahatani kopi Arabika di Kabupaten Gayo.

\section{METODOLOGI}

Penelitian dilakukan di dua desa di
Simalungun, yaitu Desa Bangun Pane dan Desa Bintang Mariah. Pemilihan lokasi ditentukan secara sengaja (purposive) dengan pertimbangan bahwa di dua desa tersebut dominan petani melakukan usahatani kopi arabika. Penelitian dilaksanakan pada bulan Agustus hingga September 2018.

Berdasarkan informasi dari petugas penyuluh pertanian, terdapat sekitar 1,000 rumah tangga petani kopi arabika di Kecamatan Dolog Masagal, namun tidak diperoleh data yang pasti tentang jumlah petani yang memiliki usahatani kopi arabika di setiap desa. Dari populasi tersebut, diambil 60 rumah tangga sebagai sampel dengan metode sampel bola salju (snowball sampling), yaitu masing-masing 30 rumah tangga petani setiap desa. Teknik snowball sampling digunakan mengingat persyaratan sampel yang ditetapkan adalah petani yang memiliki usahatani kopi arabika dengan populasi tanaman kopi arabika minimal 300 pohon dan umur tanaman kopi arabika minimal tiga tahun. Data primer dikumpulkan dengan wawancara langsung dengan bantuan tiga orang mahasiswa sebagai tenaga enumerator.

Ukuran data yang digunakan merupakan gabungan dari data skala dan rasio. Data mengenai sikap, pendapat, dan persepsi petani diukur dengan menggunakan Skala Likert dengan kategori sebagai berikut: skala Sangat Baik (skor 5), Baik (skor 4), Cukup (skor 3), Kurang (skor 2), dan Sangat Kurang (skor 1). Sementara data pendidikan, pengalaman, umur petani, dan jumlah tanggungan, diukur dengan data rasio. Variabel dan indikator variabel penelitian disajikan pada Tabel 1 .

Kecamatan Dolog Masagal, Kabupaten

Tabel 1. Variabel, indikator, dan pengukuran indikator

\begin{tabular}{lll}
\hline Variabel & Indikator variabel & Ukuran data \\
\hline Kinerja & Kreativitas petani & Skala \\
kewirausahaan & 1. Ide baru pemupukan & \\
$($ Y) & 2. Cara baru pengendalian hama dan penyakit & \\
& 3. Perubahan manajemen usahatani & \\
& 4. Sikap kritis terhadap metode usahatani anjuran & Skala \\
& Prestasi petani & \\
& 1. Kemampuan meningkatkan produksi & \\
\hline
\end{tabular}




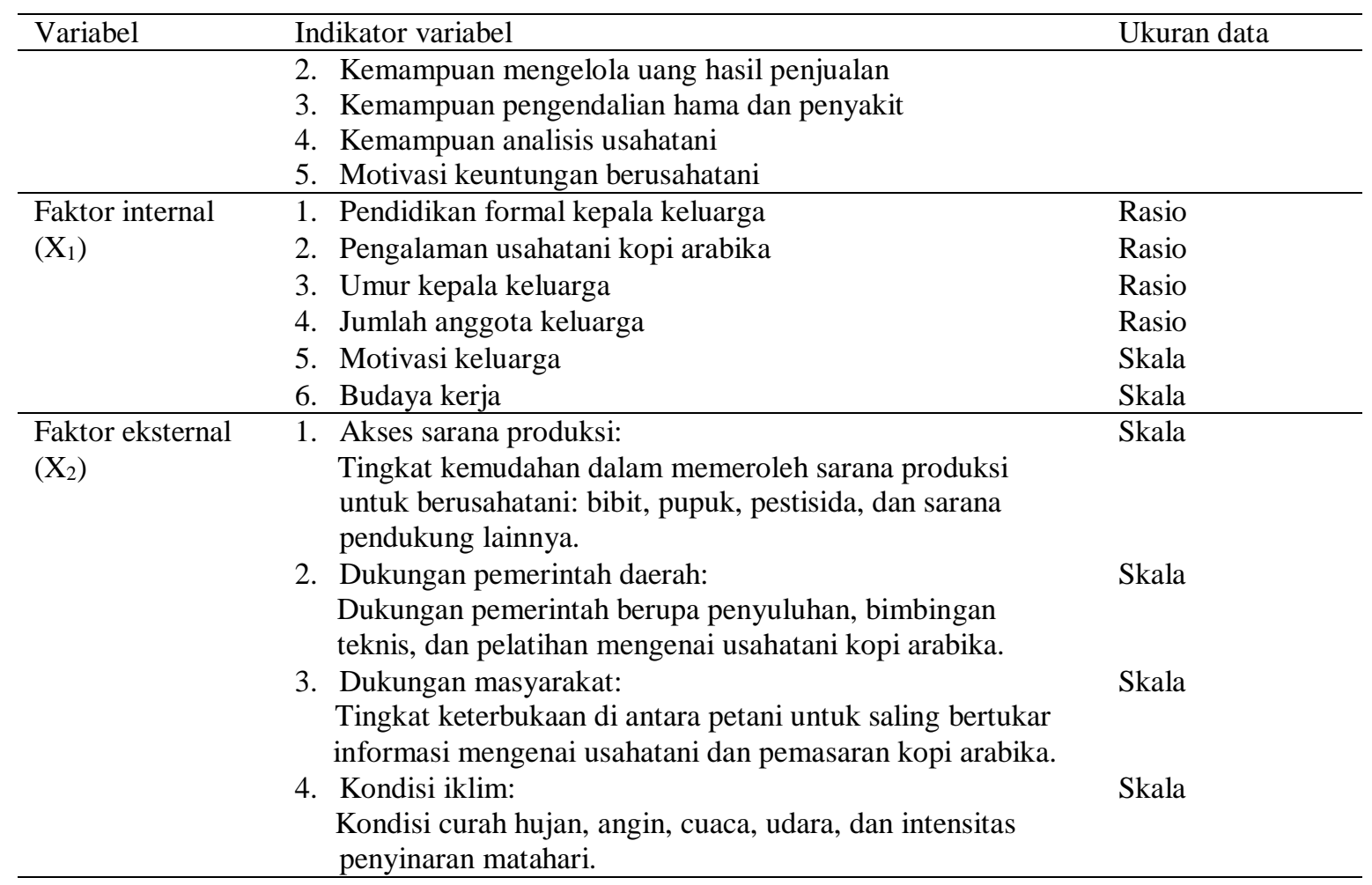

Uji validitas digunakan untuk melihat kemampuan masing-masing pernyataan dalam instrumen penelitian dalam mengukur dengan tepat indikator yang diukur. Uji Validitas dilakukan dengan menggunakan output program SPSS 24. Validitas penelitian menggunakan metode Corrected Item-Total Correlation (Pratisto, 2009). Corrected Item-Total Correlation merupakan representasi dari $\mathrm{r}$ hitung. Jika r-hitung lebih besar dari r-tabel, maka item pernyataan dalam instrumen dianggap valid (Fridayanthie, 2016).

Uji reliabilitas digunakan untuk melihat konsistensi instrumen penelitian dalam mengukur apa yang diukur. Tingkat reliabilitas instrumen ditentukan berdasarkan nilai alpha Cronbach dari output SPSS 24, sebagaimana disajikan pada Tabel 2.

Tabel 2. Tingkat reliabilitas instrumen

\begin{tabular}{cl}
\hline $\begin{array}{c}\text { Nilai alpha } \\
\text { Cronbach }\end{array}$ & Tingkat reliabilitas \\
\hline $0.0-0.2$ & Kurang Reliabel \\
$>0.2-0.4$ & Agak Reliabel \\
$>0.4-0.6$ & Cukup Reliabel \\
$>0.6-0.8$ & Reliabel \\
$>0.8-1.0$ & Sangat Reliabel
\end{tabular}

Sumber: Hair et al. (1998) dalam Arif dan Santoso (2016)
Untuk mengetahui pengaruh faktor internal dan faktor eksternal terhadap kinerja kewirausahaan petani kopi arabika digunakan analisis regresi linier berganda dengan persamaan sebagai berikut:

$$
\mathrm{Y}=\mathrm{a}+\mathrm{b}_{1} \mathrm{X}_{1}+\mathrm{b}_{2} \mathrm{X}_{2}
$$

dimana $\mathrm{Y}$ adalah variabel kinerja kewirausahaan petani kopi arabika; $\mathrm{X}_{1}$ adalah variabel (faktor) internal; dan $\mathrm{X}_{2}$ adalah variabel (faktor) eksternal.

Uji yang relevan dengan persamaan regresi linier berganda dilakukan yaitu analisis koefisien determinasi $\left(\mathrm{R}^{2}\right)$, uji pengaruh secara simultan (uji F), dan uji pengaruh secara parsial (uji t). Pengolahan data untuk persamaan regresi linier berganda dilakukan dengan program SPSS 24.

\section{HASIL DAN PEMBAHASAN}

\section{Karakteristik Petani dan Usahatani}

Umur petani kopi arabika di wilayah penelitian masih tergolong muda dimana $73 \%$ berada pada kisaran umur 20 hingga 50 tahun dengan umur rata-rata 46 tahun (Tabel 3). Menurut Asih (2009), kisaran umur 25 hingga 
50 tahun merupakan usia petani produktif dan dapat mencurahkan tenaga kerja fisik secara optimal. Karakteristik umur petani kopi arabika di wilayah penelitian ini hampir sama dengan hasil penelitian Sunanto et al. (2019) di Kabupaten Toraja Utara Provinsi Sulawesi Selatan. Usia petani kopi arabika dilaporkan dalam penelitian tersebut adalah $80 \%$ berada pada usia produktif, yaitu 25 hingga 55 tahun. Di wilayah Jawa Barat dan Banten, Puspitasari et al. (2018) melaporkan usia petani produktif sebesar $84 \%$ berada pada kisaran 25 hingga 56 tahun. Sementara penelitian Mahyuda et al. (2018) di Kabupaten Aceh Tengah Provinsi Aceh, dilaporkan sekitar $60 \%$ petani kopi arabika berada pada usia muda (19 hingga 32 tahun) dan usia sedang (33 hingga 45 tahun). Selebihnya, sekitar $40 \%$ berada pada usia tua (46 hingga 58 tahun) sampai usia lanjut (> 58 tahun).

Tingkat pendidikan petani sebesar $76 \%$ berada pada kisaran SMP sampai lulusan perguruan tinggi dengan rata-rata 12 tahun. Usia produktif dan tingkat pendidikan yang semakin tinggi menjadi faktor pendukung untuk pengembangan kewirausahaan di kalangan petani kopi arabika di Kabupaten Simalungun. Dengan pendidikan yang lebih tinggi, petani menjadi lebih dinamis dan lebih mudah menerima perubahan dan inovasi baru. Suryani et al. (2017) menyatakan bahwa tingkat pendidikan menentukan perilaku seseorang dan mempengaruhi pertimbangan rasional dalam menerima informasi maupun pengambilan keputusan teknologi.

Sebagian besar petani $(57 \%)$ memiliki pengalaman berusahatani kopi arabika pada kisaran 5 hingga 10 tahun dengan rata-rata 9 tahun. Merujuk hasil penelitian Mahyuda et al. (2018), pengalaman rata-rata petani kopi arabika di daerah penelitian ini (Kabupaten Simalungun) berada dalam pengalaman berusahatani rendah (2 hingga 10 tahun).

Tabel 3. Karakteristik responden

\begin{tabular}{lcc}
\hline Karakteristik & Jumlah & $\%$ \\
\hline Umur petani (tahun): & & \\
$20-30$ & 8 & 13 \\
$31-40$ & 20 & 33
\end{tabular}

\begin{tabular}{lcc}
\hline Karakteristik & Jumlah & $\%$ \\
\hline $41-50$ & 18 & 30 \\
$51-60$ & 10 & 17 \\
$61-70$ & 4 & 7 \\
Rerata & 46 & \\
\hline Pendidikan (tahun): & & \\
Akademi/PT & 2 & 3 \\
SMA & 24 & 40 \\
SMP & 20 & 33 \\
SD & 14 & 23 \\
Rerata & 12 & \\
\hline Pengalaman (tahun): & & \\
$5-10$ & 34 & 57 \\
$11-15$ & 20 & 33 \\
$16-20$ & 6 & 10 \\
Rerata & 9 & \\
\hline Luas lahan (ha): & & \\
0.6 & 12 & 20 \\
0.8 & 10 & 17 \\
1.0 & 18 & 30 \\
1.2 & 20 & 33 \\
Rerata & 0.7 & \\
\hline Populasi tanaman kopi: & & 3 \\
$>1,500$ & 2 & 37 \\
$1,000-1,500$ & 28 & \\
$500-1,000$ & 28 & \\
$<500$ & 2 & \\
Rerata & 1,007 & \\
\hline
\end{tabular}

Luas usahatani rata-rata adalah 0.7 ha dengan jumlah populasi tanaman kopi rata-rata sebanyak 1,007 tanaman. Berdasarkan kriteria Audry dan Djuwendah (2018), petani di daerah penelitian dikelompokkan menjadi petani dengan luas lahan sempit (<0.5 ha) sebanyak $0 \%$, petani dengan luas lahan sedang $(0.5-1.0$ ha) sebanyak 40 orang atau $67 \%$, dan petani dengan lahan luas ( $>1$ ha) sebanyak 20 orang atau $33 \%$.

\section{Uji Validitas}

Uji validitas dilakukan untuk mengetahui apakah indikator variabel yang ditentukan valid sebagai penciri variabel yang diukur. Validitas indikator ditentukan berdasarkan r-hitung, dimana apabila r-hitung > r-tabel (0.254) maka indikator dinyatakan valid, dan sebaliknya. Uji validitas disajikan pada Tabel 4.

Tabel 4 menunjukkan bahwa terdapat hanya satu indikator (item pernyataan) yang tidak valid. Dengan demikian, pernyataanpernyataan dalam instrumen penelitian ini yang merupakan indikator-indikator dari variabel penelitian, dapat dinyatakan valid. 
Tabel 4. Uji validitas

\begin{tabular}{lccc}
\hline Variabel & Item & r-hitung & Validitas \\
\hline Faktor internal & & & \\
$\begin{array}{l}\text { Pendidikan } \\
\text { Pengalaman }\end{array}$ & X1.1 & 0.256 & valid \\
Umur petani & X1.3 & 0.381 & valid \\
Jumlah tanggungan & X1.4 & 0.379 & valid \\
Motivasi keluarga & X1.5 & 0.518 & valid \\
& & & \\
Faktor eksternal & & & \\
$\begin{array}{l}\text { Dukungan } \\
\text { pemerintah }\end{array}$ & $\mathrm{X} 2.1$ & 0.398 & valid \\
$\begin{array}{l}\text { Dukungan } \\
\text { masyarakat }\end{array}$ & $\mathrm{X} 2.2$ & 0.069 & tidak \\
$\begin{array}{l}\text { Sarana dan } \\
\text { prasarana }\end{array}$ & $\mathrm{X} 2.3$ & 0.972 & valid \\
$\begin{array}{l}\text { Budaya kerja petani } \\
\text { Perkembangan }\end{array}$ & $\mathrm{X} 2.4$ & 0.379 & valid \\
iklim & $\mathrm{X} 2.5$ & 0.726 & valid \\
& & & \\
$\begin{array}{l}\text { Kinerja } \\
\text { kewirausahaan }\end{array}$ & & & \\
$\begin{array}{l}\text { Kreativitas } \\
\text { Prestasi }\end{array}$ & $\mathrm{Y} 1$ & 0.379 & valid \\
\hline & $\mathrm{Y} 2$ & 0.434 & valid \\
\hline
\end{tabular}

\section{Uji Reliabilitas}

Berdasarkan Tabel 5 dapat dinyatakan bahwa nilai alpha Cronbach ketiga variabel penelitian berada pada kisaran $>0.4$ hingga 0.6 , maka ketiga variabel termasuk kategori cukup reliabel (Hair et al., 1998 dalam Arif \& Santoso, 2016). Dengan demikian, instrumen penelitian atau kuesioner yang digunakan dalam penelitian ini dinyatakan cukup reliabel.

Tabel 5. Uji reliabilitas instrumen

\begin{tabular}{lcl}
\hline Variabel & $\begin{array}{c}\text { Alpha } \\
\text { Cronbach }\end{array}$ & Reliabilitas \\
\hline Faktor Internal $\left(\mathrm{X}_{1}\right)$ & 0.594 & $\begin{array}{l}\text { Cukup } \\
\text { Reliabel }\end{array}$ \\
Faktor Eksternal & & $\begin{array}{l}\text { Cukup } \\
\left(\mathrm{X}_{2}\right)\end{array}$ \\
$\begin{array}{l}\text { Kinerja } \\
\text { Kewirausahaan }(\mathrm{Y})\end{array}$ & 0.412 & $\begin{array}{l}\text { Reliabel } \\
\text { Cukup }\end{array}$ \\
\hline
\end{tabular}

\section{Kinerja Kewirausahaan Petani}

Variasi kinerja kewirausahaan petani yang dapat dijelaskan oleh faktor internal dan faktor eksternal diukur dengan koefisien determinasi $\left(\mathrm{R}^{2}\right)$. Koefisien determinasi $\left(\mathrm{R}^{2}\right)$ adalah 0.291 yang artinya variasi kinerja kewirausahaan petani kopi arabika dapat dijelaskan oleh faktor internal dan faktor eksternal hanya sebesar $29.1 \%$ sedangkan sisanya sebesar $71.9 \%$ dijelaskan oleh variabel yang tidak disertakan dalam persamaan.

Berdasarkan nilai $\mathrm{R}^{2}$ ini dapat disimpulkan bahwa identifikasi variabel internal dan variabel eksternal belum dapat secara utuh menggambarkan faktor penentu kinerja kewirausahaan di wilayah penelitian. Nilai $\mathrm{R}^{2}$ yang relatif rendah memberikan indikasi bahwa terdapat variabel lain yang lebih menentukan kinerja kewirausahaan, namun variabel tersebut belum dimasukkan ke dalam persamaan regresi linier berganda yang digunakan. Dengan demikian, sangat terbuka penelitian lanjutan di wilayah yang sama untuk menemukan variabel lain yang lebih dominan menentukan kinerja kewirausahaan petani kopi arabika.

Sementara untuk mengetahui pengaruh faktor internal dan faktor eksternal secara bersama terhadap kinerja kewirausahaan petani kopi arabika, dilakukan dengan uji simultan (ujiF). Berdasarkan output SPSS 24, nilai Sig untuk uji-F adalah 0.010. Karena nilai Sig. $<0.05$, maka variabel internal dan eksternal secara simultan berpengaruh nyata terhadap kinerja kewirausahaan petani kopi arabika di Kecamatan Dolog Masagal, Kabupaten Simalungun dengan tingkat kepercayaan $95 \%$.

Untuk mengetahui pengaruh variabel internal dan eksternal secara parsial terhadap kinerja kewirausahaan petani kopi arabika, dilakukan uji-t. Berdasarkan Tabel 6 dapat ditulis persamaan regresi linier berganda sebagai berikut:

$$
\mathrm{Y}=7.261+0.208 \mathrm{X}_{1}+0.236 \mathrm{X}_{2}
$$

Nilai Sig variabel internal adalah $0.005<$ 0.01. Dengan demikian, variabel internal berpengaruh sangat nyata terhadap kinerja kewirausahaan petani kopi arabika di Kecamatan Dolog Masagal dengan tingkat kepercayaan $99 \%$. Artinya bahwa faktor internal dalam keluarga petani (pendidikan, pengalaman, umur petani, jumlah tanggungan, dan motivasi keluarga) berpengaruh sangat nyata terhadap kinerja kewirausahaan petani. 
Hasil penelitian ini mendukung hasil penelitian Siahaan \& Martauli (2019) yang menemukan bahwa ketekunan, ketanggapan terhadap peluang usaha, inovatif, keberanian mengambil risiko dan kemandirian dalam menjalankan usahatani kopi berperan penting dalam peningkatan kinerja usahatani kopi arabika di Kabupaten Karo, Provinsi Sumatera Utara. Hal yang hampir sama juga terkonfirmasi dalam hasil penelitian Sumantri et al. (2013) yang menemukan bahwa peningkatan pendidikan, pelatihan, usia, pengalaman bisnis, dan latar belakang keluarga dapat meningkatkan kinerja usaha wirausaha wanita di Bogor. Sebagaimana dinyatakan sebelumnya, peningkatan kreativitas dan prestasi tersebut diukur dari ide dan kemampuan petani dalam cara pemupukan, pengendalian hama dan penyakit, manajemen usahatani, serta peluang peningkatan prestasi dalam meningkatkan produksi, pengelolaan keuangan, prediksi keuntungan dan harga jual, dan sifat komersil di kalangan petani.

Penelitian Zainura et al. (2016) di Kabupaten Gayo menemukan hal yang menarik dan mendukung hasil penelitian di Kabupaten
Simalungun ini. Karakteristik individu (internal factor) petani kopi arabika Gayo berpengaruh positif dan signifikan terhadap perilaku kewirausahaan; selanjutnya perilaku kewirausahaan berpengaruh positif dan signifikan terhadap kinerja usahatani kopi arabika Gayo.

Sementara itu, nilai Sig variabel eksternal adalah $0.313>0.05$. Dengan demikian, variabel eksternal tidak berpengaruh nyata terhadap kinerja kewirausahaan petani kopi arabika di Kecamatan Dolog Masagal dengan tingkat kepercayaan $95 \%$. Variabel eksternal yang diukur dari dukungan pemerintah, dukungan masyarakat, akses sarana prasarana, budaya kerja petani kopi arabika dan perkembangan iklim, tidak berpengaruh nyata terhadap kinerja kewirausahaan (kreativitas dan prestasi) petani kopi arabika. Penelitian Siahaan \& Martauli (2019) menemukan bahwa faktor lingkungan yang terdiri dari input, penyuluhan, bantuan modal, promosi, regulasi, kekompakan di antara petani, dan akses informasi secara nyata berpengaruh negatif terhadap kinerja usahatani kopi arabika di Kabupaten Karo Provinsi Sumatera Utara.

Tabel 6. Hasil analisis regresi berganda untuk uji pengaruh secara parsial (uji t)

\begin{tabular}{lcccc}
\hline Variabel & Koefisien Regresi & Simpangan baku & t-hitung & Sig. \\
\hline Konstanta & 7.261 & 5.016 & 1.448 & 0.159 \\
Faktor Internal & $0.208^{* *}$ & 0.068 & 3.043 & 0.005 \\
Faktor Eksternal & 0.236 & 0.230 & 1.027 & 0.313 \\
\hline
\end{tabular}

Keterangan: ** berpengaruh signifikan terhadap kinerja kewirausahaan

Hal ini berarti bahwa faktor eksternal kurang memberikan pengaruh terhadap kinerja kewirausahaan petani, dalam pengembangan usahatani. Dengan kata lain, aspek dukungan pemerintah daerah, lembaga keuangan, sarana dan prasarana, penyedia input produksi berperan kurang nyata dalam pemberdayaan petani kopi arabika, sehingga kurang mendukung kinerja petani dalam pengembangan usahatani kopi arabika. Hasil penelitian Novanda (2019) menemukan hal yang lebih baik, dimana kelembagaan, pembiayaan, dan kemandirian berpengaruh signifikan terhadap kewirausahaan petani di Kabupaten Menpawah, Provinsi Kalimantan Barat.

\section{KESIMPULAN}

Faktor internal berpengaruh positif dan nyata terhadap kinerja kewirausahaan petani kopi arabika. Faktor internal terdiri dari umur petani, pendidikan, pengalaman berusahatani kopi arabika, jumlah tanggungan keluarga, dan motivasi keluarga. Peningkatan kreativitas dapat berupa inovasi baru dalam pemupukan dan caracara baru dalam pengendalian hama dan penyakit tanaman kopi arabika. Sementara 
peningkatan prestasi dapat dicirikan oleh kemampuan meningkatkan produksi, kemampuan mengelola hasil penjualan, kemampuan prediksi keuntungan usahatani, dan prediksi harga jual kopi arabika.

Faktor eksternal berpengaruh positif dan tidak nyata terhadap kinerja kewirausahaan petani. Faktor eksternal terdiri dari dukungan pemerintah, dukungan masyarakat, akses sarana produksi, dan perkembangan iklim. Hal ini mengandung makna bahwa selama ini faktor eksternal kurang berperan dalam peningkatan kinerja kewirausahaan petani kopi arabika. Hal ini memberikan implikasi bahwa akses atas sarana produksi belum baik; dukungan penyuluhan, bimbingan teknis, dan pelatihan, belum optimal; dan keterbukaan informasi di kalangan petani masih perlu ditingkatkan. Rekomendasi yang dapat diajukan adalah pemerintah daerah melalui dinas teknis terkait dapat memberikan fasilitasi kepada petani untuk lebih mudah memeroleh sarana produksi, meningkatkan jumlah dan kualitas layanan penyuluhan, dan memberikan bimbingan teknis dan pelatihan yang dibutuhkan petani kopi arabika.

\section{DAFTAR PUSTAKA}

Arif, I. \& Santoso, B. (2016). Analisis Usabilitas Sistem Informasi Perpustakaan (Sipus) Integrasi UGM. Berkala Ilmu Perpustakaan dan Informasi, 12 (2), 104-112.

Asih, D. N. (2009). Analisis Karakteristik dan Tingkat Pendapatan Usahatani Bawang Merah di Sulawesi Tengah. J. Agroland, 16 (1), 53-59.

Audry, R. J. \& Djuwendah, E. (2018). Analisis Pendapatan Usahatani Kopi Java Preanger pada Kelompok Tani Margamulya Desa Margamulya Kecamatan Pengalengan Bandung. Jurnal Ilmu Pertanian dan Peternakan, 6 (1), 31-38.

Badan Penelitian dan Pengembangan Provinsi Sumatera Utara. (2019). Pengembangan Klaster Inovasi Produk Unggulan daerah (PUD) Kopi Provinsi Sumatera Utara, Badan Penelitian dan Pengembangan Provinsi Sumatera Utara, Medan.
Dinas Perkebunan Provinsi Sumatera Utara. (2013). Rencana Strategis Dinas Perkebunan Provinsi Sumatera Utara Tahun 2013-2018, Dinas Perkebunan Provinsi Sumatera Utara, Medan.

Direktorat Jenderal Perkebunan. (2015). Rencana Strategis Direktorat Jenderal Perkebunan tahun 2015-2019, Direktorat Jenderal Perkebunan Kementerian Pertanian, Jakarta.

Direktorat Jenderal Perkebunan. (2019). Luas Areal dan Produksi Perkebunan Seluruh Indonesia Menurut Provinsi dan Status Pengusahaan: Komoditas Kopi. http://www.ditjenbun. go.id.

Direktorat Jenderal Perkebunan. (2020). Pembangunan Perkebunan 2019, Laporan Tahunan 2019 Direktorat Jenderal Perkebunan Kementerian Pertanian, Jakarta.

Direktorat Kajian Strategis dan Kebijakan Pertanian Institut Pertanian Bogor. (2017). Peran Komoditas Kopi bagi Perekonomian Indonesia, Policy Brief No. 13, Direktorat Kajian Strategis dan Kebijakan Pertanian Institut Pertanian Bogor.

Fridayanthie, E. W. (2016). Analisa Sistem Informasi Upload Promosi Harga Menggunakan SAP terhadap Kepuasan Pengguna pada PT. Hero Supermarket Tbk. Jurnal Khatulistiwa Informatika, 4 (1), 30-43.

Mahyuda, Amanah, S., \& Tjitropranoto, P. (2018). Tingkat Adopsi Good Agricultural Practices Budidaya Kopi Arabika Gayo oleh Petani di Kabupaten Aceh Tengah. Jurnal Penyuluhan, 14 (2), 308-323.

Novanda, R. Z. (2019). Pengaruh Kelembagaan, Pembiayaan, dan Kemandirian terhadap Kewirausahaan Petani Padi Metode Hazton di Kabupaten Menpawah Kalimantan Barat. Journal of Agricultural Socioeconomics and Business, 2 (2), 1-9.

Pratisto, A. (2009). Statistik Menjadi Mudah dengan SPSS 17. Jakarta: Elex Media Komputindo.

Puspitasari, Nurmalina, R., Fariyanti, A., \& Kiloes, A. M. (2018). Pengaruh Faktor Internal dan Eksternal terhadap Perilaku Kewirausahaan dan Dampaknya terhadap Kinerja Usaha Petani Anggrek. Jurnal Hortikultura, 28 (2), 299-310.

Saragih, J. R. (2018). Aspek Ekologis dan Determinan Produksi Kopi Arabika Spesialti di Wilayah Dataran Tinggi Sumatera Utara. Jurnal Wilayah dan Lingkungan, 6 (2), 74-87. 
Siahaan, L. M. \& Martauli, E. D. (2019). Pengaruh Perilaku Kewirausahaan terhadap Kinerja Usahatani Kopi Arabika di Kabupaten Karo. Prosiding Seminar Nasional Hasil Riset dan Pengabdian, 514-523. Surabaya.

Sumantri, B., Fariyanti, A., \& Winandi, R. (2013). Faktor-Faktor yang Berpengaruh terhadap Kinerja Usaha Wirausaha Wanita: Suatu Studi pada Industri Pangan Rumahan di Bogor. Jurnal Manajemen Teknologi, 12 (3), 252277.

Sumarti, T., Rokhani, \& Falatehan, S. F. (2017). Strategi Pemberdayaan Petani Muda Kopi Wirausaha di Kabupaten Simalungun. Jurnal Penyuluhan, 13 (1), 31-39.

Sunanto, S., Salim, S., \& Rauf, A. W. (2019). Analisis Kesepakatan Peningkatan

Produktivitas Kopi Arabika pada Pengembangan Kawasan di Kabupaten Toraja Utara. Jurnal Sosial Ekonomi Pertanian, 15 (1), 42-55.

Suryani, A., Fatchiya, A., \& Susanto, D. (2017). Keberlanjutan Penerapan Teknologi Pengelolaan Pekarangan oleh Wanitatani di Kabupaten Kuningan. Jurnal Penyuluhan, 13 (1), 50-63.

Zainura, U., Kusnadi, N., \& Burhanuddin. (2016). Perilaku Kewirausahaan Petani Kopi Arabika Gayo di Kabupaten Bener Meriah Provinsi Aceh. Jurnal Penyuluhan, 12 (2), 126-143. 